Radiocarbon, Vol 57, Nr 5,2015,pQrirected Proofs

(C) 2015 by the Arizona Board of Regents on behalf of the University of Arizona

\title{
ONE-YEAR-LONG CONTINUOUS AND SYNCHRONOUS DATA SET OF FOSSIL CARBON IN ATMOSPHERIC PM 2.5 AND CARBON DIOXIDE IN DEBRECEN, HUNGARY
}

\author{
István Major ${ }^{1,2} \bullet$ Enikő Furu $^{3}$ László Haszpra ${ }^{4,5} \cdot$ Zsófia Kertész $^{2} \cdot$ Mihály Molnár $^{1}$
}

\begin{abstract}
Radiocarbon investigation of atmospheric $\mathrm{PM}_{2.5}$ aerosol synchronized with ${ }^{14} \mathrm{CO}_{2}$ observations began in Debrecen in the winter of 2010. The aim of the study was to determine the contemporary and fossil carbon fractions in the aerosol and to set them against the fossil $\mathrm{CO}_{2}$ excess data referring to the same period. The mass of the collected $\mathrm{PM}_{2.5}$ mode on prebaked quartz filters was determined gravimetrically, while its total carbon mass was calculated from the pressure of $\mathrm{CO}_{2}$ gas produced after the combustion of the filters. As a result of the applied sampling and preparation method, the stable, nonvolatile carbon forms were principally studied. ${ }^{14} \mathrm{C}$ measurements of the tiny aerosol bulk samples were performed using the EnvironMICADAS accelerator mass spectrometer at ATOMKI. The sample preparation method was tested using several blanks, standards, and real samples. Test results showed good reproducibility for the applied aerosol sample preparation and accelerator mass spectrometry (AMS) ${ }^{14} \mathrm{C}$ analyses. Atmospheric fossil $\mathrm{CO}_{2}$ excess data were calculated according Levin et al. (2003), using the ${ }^{14} \mathrm{C}$ results of collected $\mathrm{CO}_{2}$ samples measured by the gas proportional counting system at ATOMKI. Mass concentration of $\mathrm{PM}_{10}$ involving the $\mathrm{PM}_{2.5}$ mode in the city air exceeded the daily average of $50 \mu \mathrm{g} / \mathrm{m}^{3}$ (24-hr limit value in the EU) several times in 2011, mainly during the winter. The results showed that recently derived carbon most likely from domestic wood burning was causing the elevated carbon mass concentration of $\mathrm{PM}_{2.5}$ in Debrecen at the time. In the course of the 1-yr-long continuous and systematic comparison of fossil carbon mass concentration of $\mathrm{PM}_{2.5}$ mode and mole fraction of fossil excess of atmospheric $\mathrm{CO}_{2}$, similar and synchronous trends were observed during the studied period in Debrecen.
\end{abstract}

\section{INTRODUCTION}

Atmospheric particulate matter including carbonaceous aerosol directly influences the change of climate and the quality of the environment, causing a direct threat to human health (Künzli et al. 2000; Ramanathan et al. 2007). It is difficult to give an unambiguous definition for the chemical composition of carbonaceous aerosol, as the particles are made up of a mixture of numerous simple components and various complex compounds (Chow et al. 2004). Disregarding the inorganic carbonates (CC), based on a "top-down" approach, the total carbon content (TC) of aerosol is made up of subfractions of organic carbon (OC) derived primarily and secondarily from both natural and anthropogenic sources and graphite-like elemental carbon (EC/soot), resulting mostly from incomplete anthropogenic combustion processes (Novakov et al. 1997; Kriváncsy et al. 2001; Chow and Watson 2002). Concerning the $\mathrm{PM}_{2.5}$ mode, the total carbon content can be as high as $20-50 \%$ of the total aerosol mass of urban and rural sites (Rogge et al. 1993; Cachier 1998; Turpin et al. 2000; Pöschl 2005). Molnár et al. (1999), in a study regarding PM $_{2.5}$ aerosol samples taken intermittently during the summer at the rural site of K-puszta (Hungarian meteorological monitoring station; $46^{\circ} 58^{\prime} \mathrm{N}, 19^{\circ} 33^{\prime} \mathrm{E}, 125 \mathrm{~m}$ asl), reported that organic substances obtain increasing significance as their fractions can exceed $50 \%$ of the total aerosol mass. Studies showed that besides inorganic ions such as sulfate and nitrate, carbonaceous compounds can also affect the atmospheric processes due to their similar characteristics; therefore, investigation of the excess amount of anthropogenicderived carbonaceous particles is very important (Saxena et al. 1995). Regarding the health effects of the $\mathrm{PM}_{2.5}$ mode containing carbon as well, a very small change in the exposure is associated with an increase (18\%) in the risk of low birth weight; this relationship can be observed even below the currently accepted safe levels (Pedersen et al. 2013). For the public health, the European Directive 2008/50/EC provides new air quality objectives for $\mathrm{PM}_{2.5}$, including the limit value, exposure concentration obligation, and exposure reduction target.

Previously, various tracers (e.g. levoglucosan for biomass burning) have been applied to identify the sources of carbonaceous aerosol; however, their applicability was often limited by their chemical

1. Hertelendi Laboratory of Environmental Studies, MTA ATOMKI, Bem tér 18/c, H-4026 Debrecen, Hungary.

2. Corresponding author. Email: imajor@atomki.hu.

3. Laboratory of Ion Beam Applications, MTA ATOMKI, Debrecen, Hungary.

4. Hungarian Meteorological Service, Budapest, Hungary.

5. MTA Research Centre for Astronomy and Earth Sciences, Sopron, Hungary. 


\section{Corrected Proofs}

activity and atmospheric lifetime (Szidat et al. 2006). However, using ${ }^{14} \mathrm{C}$, the radioactive carbon isotope with a long half-life $\left(\mathrm{t}_{1 / 2}=5700 \pm 30 \mathrm{yr}\right)$, proved to be a suitable tracer for the distinction of the fossil and contemporary sources. ${ }^{14} \mathrm{C}$ is effective because the fossil fuels do not contain any ${ }^{14} \mathrm{C}$ due to their high geological age, while the ${ }^{14} \mathrm{C}$ content of the biomass-derived fuels approximately equals that of the atmosphere and recent biological carbon. Therefore, ${ }^{14} \mathrm{C}$ measurement makes an unambiguous distinction between the contemporary, i.e. nonfossil (e.g. biomass combustion and the biological contribution), and the fossil sources. The ${ }^{14} \mathrm{C}$ method has become essential for source apportionment of the carbonaceous fraction of aerosol. ${ }^{14} \mathrm{C}$ measurements require high precision and accuracy, which can only be achieved by the accelerator mass spectrometry (AMS) technique due to the low carbon content of the collected aerosol samples (Clayton et al. 1955; Currie 2000; Endo et al. 2004; Szidat et al. 2004, 2006, 2009; Bench et al. 2007).

The aim of this study is to estimate the origin and contributions of sources of the $\mathrm{PM}_{2.5}$ carbonaceous aerosol in Debrecen for a year-long period in 2011. Although ${ }^{14} \mathrm{C}$ measurements based on proportional counting have a long history at ATOMKI (Csongor et al. 1982; Csongor and Hertelendi 1986), no appropriate ${ }^{14} \mathrm{C}$ sample preparation and measurement system was available for carbonaceous aerosol before the installation of the new EnvironMICADAS AMS device in 2011. Thus, this article reports ${ }^{14} \mathrm{C}$ results obtained in the new AMS Laboratory in Debrecen, and used to differentiate the contemporary and fossil-derived fractions of the $\mathrm{PM}_{2.5}$ mode. The characteristics of seasonal changes of the carbonaceous aerosol mass concentration and its contemporary fraction $\left(\mathrm{f}_{\mathrm{C}}\right)$ are presented as well. Furthermore, a comparison is made between the fossil carbon fraction of the atmospheric $\mathrm{PM}_{2.5}$ observed throughout the monitoring year and the fossil excess of the atmospheric $\mathrm{CO}_{2}$ gas collected and investigated by the proportional counter technique synchronously in the same city.

\section{MATERIALS AND METHODS}

\section{Sampling Process}

Located in central eastern Hungary, Debrecen has a population of 200,000 and is the second largest city in the country. It is situated near a large agricultural region and is surrounded by cultivated areas. The sampling site is encompassed by residential areas and is located in the garden of the Institute of Nuclear Research (ATOMKI), Debrecen (Figure 1). Far from direct industrial and agricultural contamination sources, this area is specified as an urban background site according to Larssen et al. (1999).

At the institute, systematic collection of $\mathrm{PM}_{2.5}$ (fine) and $\mathrm{PM}_{10-2.5}$ (coarse) aerosol modes has been performed since 1988. A database containing the mass and elemental concentration data of $\mathrm{PM}_{2.5}$, $\mathrm{PM}_{10-2.5}$, and $\mathrm{PM}_{10}$ modes has been created using accelerator-based analytical methods (e.g. macroand micro-PIXE) (Borbély-Kiss et al. 1999). This has been accompanied by ${ }^{14} \mathrm{C}$ measurements on monthly integrated samples since November 2010.

An SKC ${ }^{\circledR}$ IMPACT PM coarse type (http://www.skcltd.com) aerosol sampler collected the $\mathrm{PM}_{2.5}$ mode of aerosol on the roof of the ATOMKI building Nr. IX, at about $5 \mathrm{~m}$ above the ground level. As the sampler is not suitable for the sampling of secondary organic aerosol formed by semi- and volatile organic compounds (SVOC and VOC, respectively), this aerosol fraction was disregarded in our investigation. The samples were collected with a flow rate of $10 \mathrm{dm}^{3}$ air/min on quartz fiber filters (Tissuquartz filter ${ }^{\circledR}$, thickness: $0.4 \mathrm{~mm}$ ) with a diameter of $47 \mathrm{~mm}$. On the day before use, the quartz filter was baked for at least $12 \mathrm{hr}$ in a muffle oven $\mathrm{t} 850^{\circ} \mathrm{C}$ to remove all carbonaceous contamination, then its mass was weighed. Each sampling month was divided into 1- and 2-weeklong periods ending with a filter change, since the filter would have possibly been clogged during 


\section{Corrected Proofs}

Fossil Carbon in Atmospheric $\mathrm{PM}_{2.5}$ and $\mathrm{CO}_{2}$ in Debrecen, Hungary

the month of collection. During the monitoring period from November 2010 to November 2011, the masses of collected $\mathrm{PM}_{2.5}$ samples were within the range of 4.27-19.48 $\mathrm{mg}$ (Table 1). The samples obtained $(n=37)$ were stored in closed plastic petri dishes at room temperature until the day of preparation.

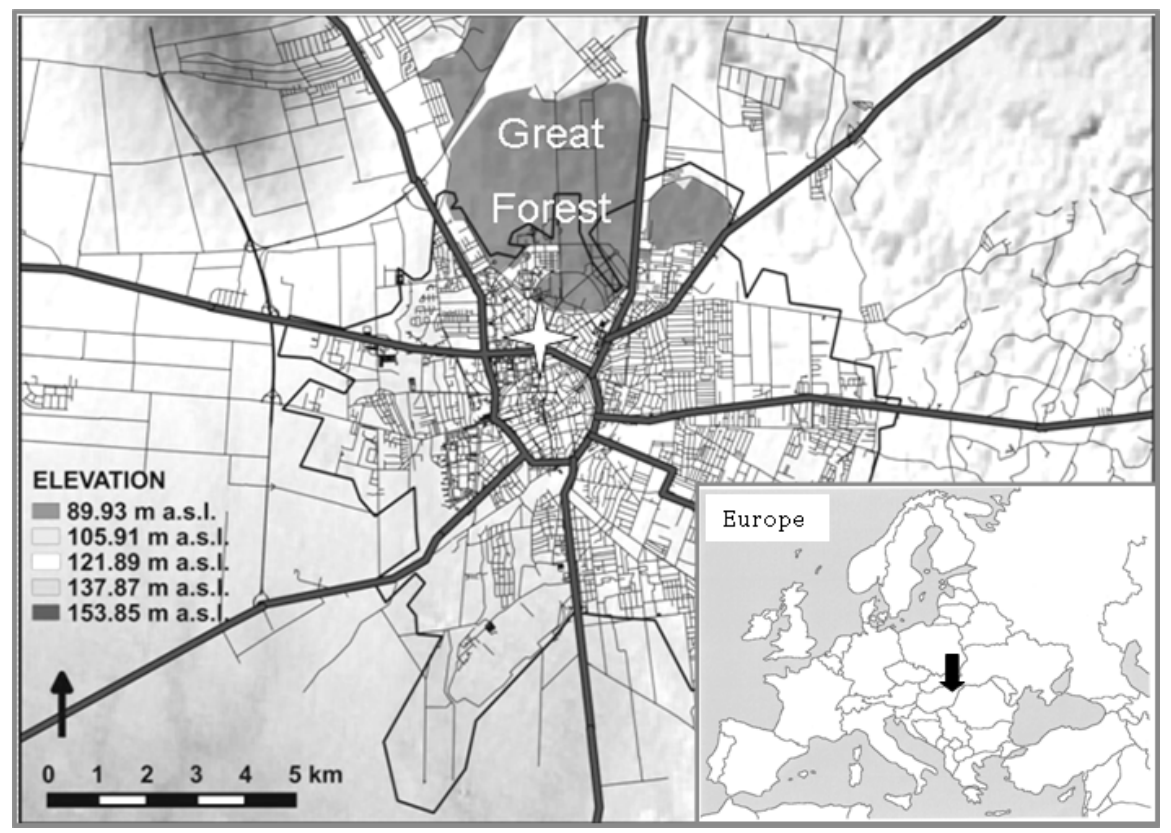

Figure 1 Map of the city of Debrecen. Both natural and anthropological sources can be found extremely close to the sampling point indicated by the white star. Dark lines correspond to primary roads with heavier traffic.

Table 1 Sampling data on the $\mathrm{PM}_{2.5}$ samples collected onto quartz filters during the investigated period.

\begin{tabular}{lllll}
\hline $\begin{array}{l}\text { Sampling period } \\
\text { (start-end) } \\
\text { dd.mm.yy }\end{array}$ & $\begin{array}{l}\text { Sample inte- } \\
\text { gration time } \\
\text { (days) }\end{array}$ & $\begin{array}{l}\text { Sampled } \\
\text { air volume } \\
\left(\mathrm{m}^{3}\right)\end{array}$ & $\begin{array}{l}\mathrm{PM}_{2.5} \text { mass } \\
\text { on filter } \\
(\mathrm{mg})\end{array}$ & $\begin{array}{l}\text { Total } \mathrm{PM}_{2.5} \\
\text { mass concen- } \\
\text { tration }\left(\mu \mathrm{g} / \mathrm{m}^{3}\right)\end{array}$ \\
\hline $03.11 .10-01.12 .10$ & 28 & 402.9 & 14.87 & 36.9 \\
$01.12 .10-05.01 .11$ & 35 & 503.0 & 15.89 & 31.6 \\
$05.01 .11-02.02 .11$ & 28 & 403.0 & 14.62 & 36.3 \\
$02.02 .11-01.03 .11$ & 27 & 344.0 & 14.05 & 40.8 \\
$01.03 .11-30.03 .11$ & 28 & 375.4 & 9.58 & 25.5 \\
$30.03 .11-04.05 .11$ & 35 & 479.8 & 7.60 & 15.8 \\
$04.05 .11-01.06 .11$ & 28 & 394.1 & 5.12 & 13.0 \\
$01.06 .11-29.06 .11$ & 28 & 380.9 & 4.27 & 11.2 \\
$29.06 .11-03.08 .11$ & 35 & 487.1 & 5.53 & 11.4 \\
$03.08 .11-31.08 .11$ & 28 & 400.8 & 5.78 & 14.4 \\
$31.08 .11-28.09 .11$ & 28 & 393.1 & 5.51 & 14.0 \\
$28.09 .11-02.11 .11$ & 35 & 486.1 & 12.42 & 25.6 \\
$02.11 .11-30.11 .11$ & 28 & 370.3 & 19.48 & 52.6 \\
\hline
\end{tabular}




\section{Corrected Proofs}

Sampling and measurements serving as a basis for the atmospheric fossil $\mathrm{CO}_{2}$ excess calculations had been performed in the city center of Debrecen and at the background site of Hegyhátsál, Hungary, since 2008. Within this investigation, the mole fraction of fossil $\mathrm{CO}_{2}$ excess in Debrecen (ATOMKI) relative to Hegyhátsál was determined by simultaneous measurement of the atmospheric $\mathrm{CO}_{2}$ mole fraction and its specific ${ }^{14} \mathrm{C}$ content at both sites. With the aim of a continuous observation, high-precision atmospheric $\mathrm{CO}_{2}$ analyzers and an ATOMKI-developed atmospheric ${ }^{14} \mathrm{CO}_{2}$ sampling device were installed at ATOMKI and the remote Hegyhátsál reference site. In Debrecen, the atmospheric $\mathrm{CO}_{2}$ mole fraction was measured by a Siemens ${ }^{\circledR}$ ULTRAMAT $6 \mathrm{~F}$ NDIR type $\mathrm{CO}_{2}$ gas analyzer with an uncertainty of $0.5 \mu \mathrm{mol} / \mathrm{mol}$. Calibration of the device was performed every $3 \mathrm{hr}$ using synthetic air-based calibration gases with a known mole fraction of $\mathrm{CO}_{2}$ (Molnár et al. 2010a). ${ }^{14} \mathrm{CO}_{2}$ samplers installed in Debrecen and Hegyhátsál were developed in ATOMKI to obtain integrated samples for measuring ${ }^{14} \mathrm{C}$ in the chemical form of $\mathrm{CO}_{2}$, which was trapped in bubblers filled with $500 \mathrm{~mL}$ of $3 \mathrm{M} \mathrm{NaOH}$ solution. The sampling period was 4 weeks long and the flow rate of sampling was stabilized at $10.0 \mathrm{~L} / \mathrm{hr}$. The absorption yield of $\mathrm{CO}_{2}$ in the $3 \mathrm{M} \mathrm{NaOH}$ solution is greater than $95 \%$ using a specially designed bubbler-type trap. A detailed description of the sampling devices is given by Uchrin and Hertelendi (1992).

\section{Sample Preparation}

${ }^{14} \mathrm{C}$ measurement was performed on the total carbon content of the $\mathrm{PM}_{2.5}$ aerosol samples. The monthly samples were combusted in the presence of oxygen, and the produced $\mathrm{CO}_{2}$ was purified in a dedicated vacuum system. Carbonates were not removed from the filters by acidification in advance because inorganic carbon species had been found to be negligible in midlatitude aerosols (Szidat et al. 2004). As a first step, the filters of $\mathrm{PM}_{2.5}$ mode were precisely cut into $1 / 8$ slices with scissors, and the slices containing the appropriate amount of carbon for the AMS measurement $(0.5-1 \mathrm{mg})$ were placed into a preheated quartz combustion tube $\left(\mathrm{QSIL}{ }^{\circledR}\right.$, $\varnothing 7 \times 150 \mathrm{~mm})$. An average estimate of $30 \mathrm{wt} \%$ total carbon content of aerosol was used for determining the necessary sample amount needed for ${ }^{14} \mathrm{C}$ AMS analyses. Then, copper oxide powder was inserted for the conversion of the total carbon to $\mathrm{CO}_{2}$ gas. The $\mathrm{CO}_{2}$ was liberated via a one-step combustion process in a high-vacuum preparation system designed for this specific purpose (Molnár et al. 2013a). To avoid any contamination, all parts of this system were made of glass, quartz, and stainless steel materials. Combustion of the sample in the quartz tube was performed using a gas flame (at $>1000^{\circ} \mathrm{C}$ ). The released $\mathrm{CO}_{2}$ was cryogenically separated from other byproduct gases. In the calibrated known-volume part of the system $\left(77.4 \mathrm{~cm}^{3}\right)$, the pressure of the purified $\mathrm{CO}_{2}$ was determined by absolute pressure measurement at room temperature.

In order to prepare graphite targets for AMS measurement, a customized sealed tube graphitization method was applied. Here, the $\mathrm{CO}_{2}$ is reduced to elemental carbon in the presence of titanium hydride, zinc, and iron catalysts in a reductive environment. Finally, the carbon is deposited on the surface of the iron in the form of graphite (Rinyu et al. 2013). The graphite obtained was pressed into aluminum target holders (ETHZ), which were then inserted into the magazine of the AMS device.

\section{Radiocarbon Methodology}

${ }^{14} \mathrm{C}$ measurement of the $\mathrm{PM}_{2.5}$ samples was performed on the EnvironMICADAS AMS (developed by ETH-Zürich, Switzerland) installed at ATOMKI, in the summer of 2011 (Molnár et al. 2013b). The carbon mass of the aerosol samples was calculated from the pressure of the $\mathrm{CO}_{2}$ obtained during the preparation. Besides the real samples, two reference samples, i.e. IAEA C9 (fossil wood) with similar carbon mass and three fossil $\mathrm{CO}_{2}$ gas samples (Linde, Répcelak, Hungary), were also prepared under the same conditions as the aerosol samples and measured for ${ }^{14} \mathrm{C}$ to check the quality of 


\section{Corrected Proofs}

Fossil Carbon in Atmospheric $\mathrm{PM}_{2.5}$ and $\mathrm{CO}_{2}$ in Debrecen, Hungary

the preparation. Based on the measurement of aerosol background samples, $9 \pm 1 \mu \mathrm{g}$ modern carbon contamination per sample was used as an average blank correction. Normalization of ${ }^{14} \mathrm{C}$ measurements was performed by measuring graphite targets made from NIST SRM 4990C oxalic acid II standards. The average $1 \sigma$ standard deviation achieved for modern samples was $\pm 0.5 \%$.

The AMS ${ }^{14} \mathrm{C}$ measurement results, i.e. the ${ }^{14} \mathrm{C} /{ }^{12} \mathrm{C}$ ratios of the samples relative to the NIST SRM $4990 \mathrm{C}$ oxalic acid II standard, are given in the internationally accepted fraction modern $\left(\mathrm{f}_{\mathrm{M}}\right)$ value (Burr and Jull 2009). The MICADAS measures the ${ }^{13} \mathrm{C} /{ }^{12} \mathrm{C}$ ratio for isotope fractionation correction on-line during ${ }^{14} \mathrm{C}$ analyses, and this value is used in the data correction and reduction process (Wacker et al. 2010). The $\mathrm{f}_{\mathrm{M}}$ value gives the activity of the sample related to the activity of a biological reference level, i.e. a tree ring formed in the Northern Hemisphere in the year 1890. Since all of the total ${ }^{14} \mathrm{C}$ content of fossil fuels has already decayed, their $\mathrm{f}_{\mathrm{M}}$ value is 0 . However, current biological aerosols are formed by recent biological sources; thus, their $\mathrm{f}_{\mathrm{M}}$ values are equal to that of the atmosphere and the current biological materials $\left(\mathrm{f}_{\mathrm{M}} \sim 1\right)$. As the majority of the currently combusted firewood was growing during the period of the ${ }^{14} \mathrm{C}$-bomb peak caused by the nuclear weapon tests (between 1960-1990) (Currie et al. 1989), the aerosol particles containing carbon from wood combustion have a ${ }^{14} \mathrm{C}$ activity slightly higher than that of the present atmosphere. According to Heal et al. (2011), the ${ }^{14} \mathrm{C}$ level of atmospheric carbonaceoius aerosol is on average 1.08 times (weighted average of 1.05 and 1.15 after Szidat et al. 2006, 2009) as high as that before the bomb effect, which was taken into correction. The fraction of the contemporary carbon $\left(\mathrm{f}_{\mathrm{C}}\right)$ in the atmospheric aerosol samples can be calculated from the fraction modern values corrected for the bomb effect using the following formula:

$$
\mathrm{f}_{\mathrm{C}}=\mathrm{f}_{\mathrm{M}} / 1.08
$$

As the main sources of total carbon content of $\mathrm{PM}_{2.5}$ aerosol are the recent biological and the fossil sources, the fraction of fossil carbon $\left(f_{\mathrm{f}}\right)$ is the remaining fraction of the total carbon:

$$
\mathrm{f}_{\mathrm{f}}=1-\mathrm{f}_{\mathrm{C}}
$$

By definition, the contemporary carbon fraction $\left(f_{C}\right)$ is between 0 and 1 , where 0 means that the entire aerosol is fossil-derived without any recent biological carbon content and 1 when the whole carbon content is recent. Therefore, $\mathrm{f}_{\mathrm{C}}$ is the extent of the direct plant contribution (AQEG 2005).

Regarding the sampling and preparation method of atmospheric $\mathrm{CO}_{2}$ gas for ${ }^{14} \mathrm{C}$ measurements, detailed information can be found in Molnár et al. (2007); therefore, the process is discussed here only briefly. ${ }^{14} \mathrm{C}$ activity measurements $\left(\Delta^{14} \mathrm{C}\right)$ of the atmospheric samples (1-month integrated samples, typical 1-2 $\mathrm{g}$ of carbon in size) were performed by our gas proportional counter (GPC) system. The standard deviation of a single $\Delta^{14} \mathrm{C}$ measurement applying this method was $\pm 0.4-0.5 \%$ after 1 week of counting per sample (Csongor et al. 1982; Csongor and Hertelendi 1986). The $\delta^{13} \mathrm{C}$ isotope ratios considered in the $\Delta^{14} \mathrm{C}$ calculation were measured on the prepared $\mathrm{CO}_{2}$ gas by a stable isotope mass spectrometer, ThermoFinnigan Delta ${ }^{\text {Plus }} \mathrm{XP}$ (typical standard deviation is $\pm 0.2 \%$ ) (Hertelendi 1990).

The mole fraction of the fossil $\mathrm{CO}_{2}$ excess was calculated for the monitoring period in Debrecen air (Molnár et al. 2010b) based on the formula described by Levin et al. (2003):

$$
c_{\text {fossil(Debrecen) }}=c_{\text {Debrecen }} \cdot \frac{\Delta^{14} \mathrm{C}_{\text {Hegyhátsál }}-\Delta^{14} \mathrm{C}_{\text {Debrecen }}}{\Delta^{14} \mathrm{C}_{\text {Hegyhátsál }}+1000}
$$




\section{Corrected Proofs}

where $c_{\text {Debrecen }}$ and $c_{\text {fossil (Debrecen) }}$ are the mole fractions of the absolute $\mathrm{CO}_{2}$ and its fossil fraction in Debrecen, respectively, in $\mu \mathrm{mol} / \mathrm{mol}$ units. The $\Delta{ }^{14} \mathrm{C}$ values are the specific quantity of the ${ }^{14} \mathrm{C}$ in $\mathrm{CO}_{2}$ at the investigated and background site (Hegyhátsál), expressed in per mil (Stuiver and Polach 1977).

\section{RESULTS}

\section{Evaluation of the $\mathrm{PM}_{2.5}$ Data Set}

The average monthly mass concentration of the $\mathrm{PM}_{2.5}$ mode, determined gravimetrically, varied from 11 to $53 \mu \mathrm{g} / \mathrm{m}^{3}$ in Debrecen during the investigated year. The amount, and consequently the mass concentration of the total carbon, of the fine mode samples was calculated from the pressure of the purified $\mathrm{CO}_{2}$ extracted after the combustion of the aerosol filters (Figure 2).

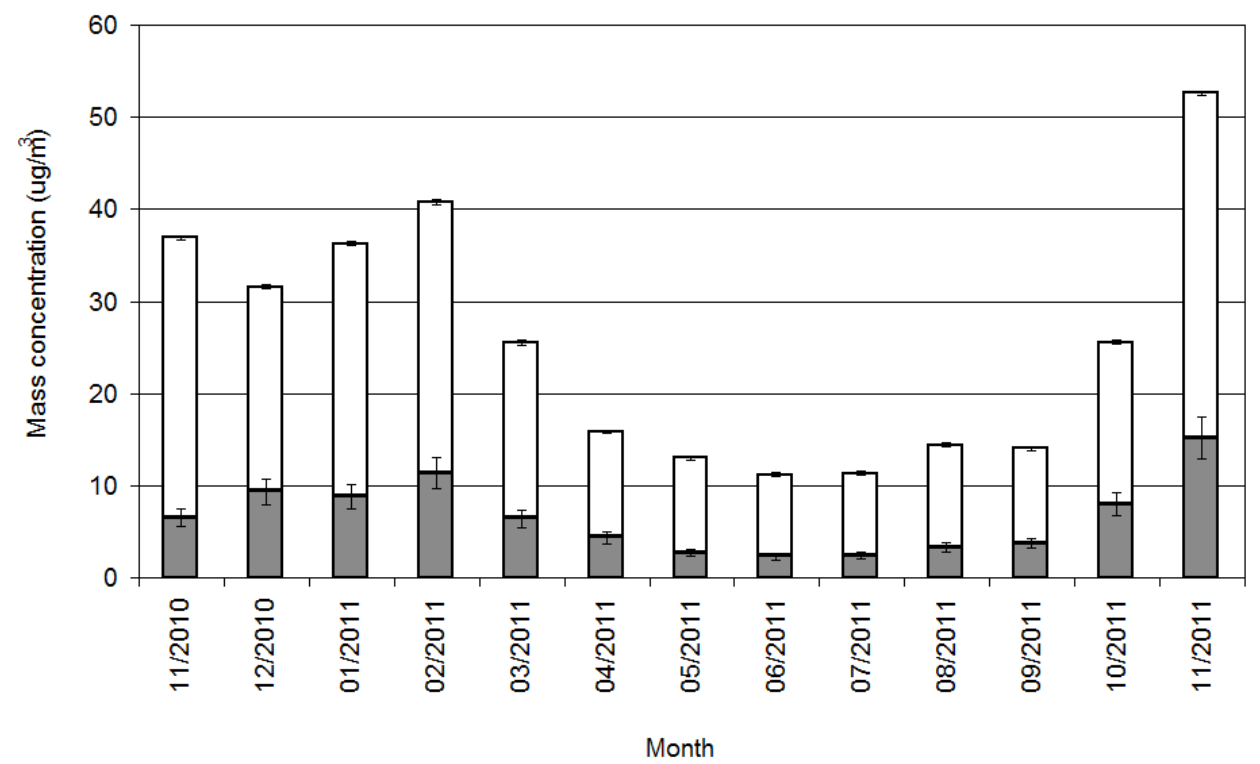

Figure 2 Monthly average mass concentrations $\left(\mu \mathrm{g} / \mathrm{m}^{3}\right)$ of the atmospheric $\mathrm{PM}_{25}$ mode during the year-long sampling period in Debrecen. Gray bars represent the total carbon fraction in the fine aerosol mode, while white bars represent all other, noncarbonaceous fractions. The sum of the two bars shows the total $\mathrm{PM}_{2.5}$ mass concentration.

After November $2010\left(36.9 \mu \mathrm{g} / \mathrm{m}^{3}\right)$, a slight decrease can be observed in December 2010, followed by an increase up to $40.8 \mu \mathrm{g} / \mathrm{m}^{3}$ in February 2011. Based on reports from the Hungarian Environmental Service (Environmental Program of Debrecen 2009-2014), during February 2011, the $\mathrm{PM}_{10}$ mass concentration in Debrecen exceeded the daily average limit value $\left(>50 \mu \mathrm{g} / \mathrm{m}^{3}\right)$ for more than 18 days. In 2011, the end of the heating period coincided with the end of March in Debrecen, after which the aerosol mass concentration started to decrease. Mass concentration data of the atmospheric $\mathrm{PM}_{2.5}$ mode showed a continuous decrease from March and reached the minimum value of $11.2 \mu \mathrm{g} / \mathrm{m}^{3}$ in July. During the summer, there was no domestic heating and the meteorological conditions facilitated a better atmospheric dilution of aerosol. In October 2011, at the beginning of the subsequent heating period in Debrecen, the mass concentration of fine aerosol began to increase again and reached a temporary maximum in November, which was four times as high as the minimum value in the summer. This time, the mass concentration of the particulate matter exceeded the alert threshold value (24-hr average $>100 \mu \mathrm{g} / \mathrm{m}^{3}$ ) in several cities of Hungary due to unfavorable meteorological conditions in the Carpathian Basin. 


\section{Corrected Proofs}

Fossil Carbon in Atmospheric $\mathrm{PM}_{2.5}$ and $\mathrm{CO}_{2}$ in Debrecen, Hungary

Regarding the carbon content of $\mathrm{PM}_{2.5}$, higher carbon mass concentrations were observed in winter and spring, i.e. during the heating period. By the beginning of winter, in December 2010, the fine aerosol mass concentration slightly decreased compared to that of November, while the total mass concentration of carbon showed a slight increase. After January 2011, the mass concentration of the fine aerosol and of total carbon followed a similar trend (Figure 2). The carbonaceous fraction was on average $25 \%$ of the mass concentration of $\mathrm{PM}_{2.5}$ in the center of Debrecen, and this value ranged from $21 \%$ in summer to $31 \%$ in winter. According to summer data from K-puszta (Hungarian meteorological monitoring station), the total carbon content was responsible for more than $50 \%$ of the total aerosol mass (Molnár et al. 1999). This is more than twice the value obtained by us (25\%) in the same period, in an urban environment. According to our year-long observation, the average noncombustible inorganic fraction can be characterized as $75 \%$ of the fine aerosol mass concentration in Debrecen. The total carbon fraction results measured in Debrecen are similar to the data ( $\sim 30 \%$ carbon content) of Heintzenberg (1989) for a nonurban continental area; however, the mean fine aerosol mass concentration observed by the author was about only half of our value. Our total carbon mass concentration data are in good agreement with the results $(20-45 \%$ carbon content) published by Putaud et al. (2010), in which data obtained over the past decade at more than 60 different types of sites across Europe are synthesized. Based on their compilation, it is clearly seen that the main constituent of the $\mathrm{PM}_{2.5}$ fraction over Europe is carbonaceous matter alongside sulfate and nitrate ions. Regarding Asia, for a year-long sampling period, Huang et al. (2010) reported that total carbon content data of $\mathrm{PM}_{2.5}$ varied between $4.65 \%$ and $21.51 \%$ with a maxima in winter and spring.

To differentiate the contribution of the contemporary and fossil sources, $\mathrm{f}_{\mathrm{C}}$ values were determined with monthly resolution during the sampling period. Within the total carbon amount, the variation of contemporary/fossil carbon ratios $\left(\mathrm{f}_{\mathrm{C}} / \mathrm{f}_{\mathrm{f}}\right)$ calculated on the basis of the ${ }^{14} \mathrm{C}$ measurements is shown in Figure 3. There is much more carbon in the fine aerosol in winter, and based on $f_{C}$ values, it can be seen that the main source of the carbon is not fossil-derived, but contemporary, which most likely originates from the domestic wood combustion by the inhabitants.

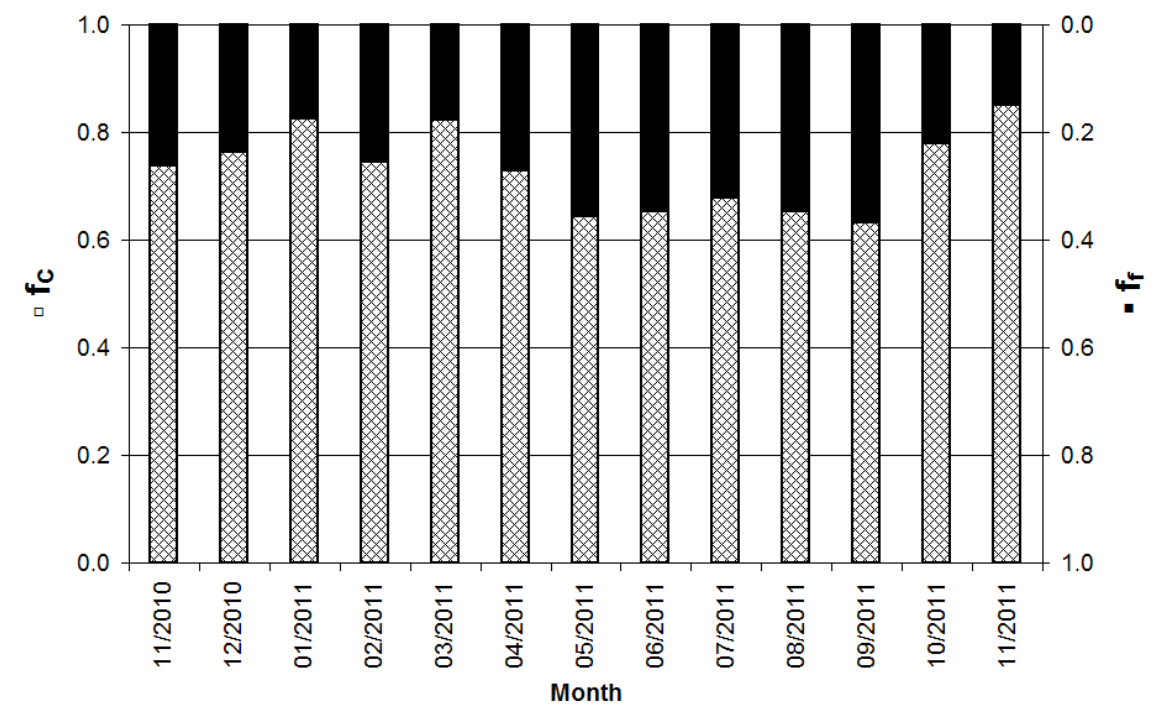

Figure 3 Temporal variation of $\mathrm{f}_{\mathrm{C}}$ and $\mathrm{f}_{\mathrm{f}}$ values determined for Debrecen during the investigated period

The average $\mathrm{f}_{\mathrm{C}}$ value was 0.73 , varying between the summer minimum (May-September) of 0.64 and the winter maximum (November) of 0.85 . According to Tanner et al. (2004), the cause of the 


\section{Corrected Proofs}

8

I Major et al.

higher carbon fraction in autumn and winter is likely the combustion of agricultural wastes and the wood burning for home heating. The same can be said of the relatively high contemporary carbon $\left(\mathrm{f}_{\mathrm{C}}\right)$ value obtained for the investigated winter period in Debrecen.

From November 2010, the carbon mass concentration and $\mathrm{f}_{\mathrm{C}}$ value increased together, showing an increased contemporary aerosol emission due to wood combustion for home heating. In February 2011 , the total $\mathrm{PM}_{2.5}$ and the total carbon mass concentration exhibited a winter maximum, probably due to the synergy of the increased emission and the unfavorable meteorological conditions. While the mass concentration of the carbon in fine mode significantly increased by February 2011, the $\mathrm{f}_{\mathrm{C}}$ value compared to the previous value fell, likely due to an increase in the contribution of fossil sources. From the consistently high contemporary carbon fraction in the fine mode, it can be concluded that the inhabitants of houses with individual heating systems preferred the use of cheaper wood instead of the more expensive fossil coal. Nevertheless, despite the fact that ubiquitous natural gas is a fossil fuel, its combustion generates relatively less aerosol emission relative to wood or coal burning, so its atmospheric fossil carbon contribution is not so significant in the fine aerosol but becomes visible via the fossil $\mathrm{CO}_{2}$ observations.

In June, the middle of summer 2011, the total carbon mass concentration showed a temporary minimum; however, the fraction of the recent biological carbon increased until July and then began to decrease. In the formation of contemporary carbon maximum in summer, the high-intensity photochemical activity and the higher concentration of secondary organic aerosol (SOA) emitted by the intensively growing plants might also play a role. The increase observed from October may be due to the combustion of agricultural wastes, biodegradation, and the beginning of wood-based heating for individual homes.

Based on the variation of mass concentration of the contemporary and fossil carbon calculated from the individual $\mathrm{f}_{\mathrm{C}}$ values and monthly total carbon data, it is clearly seen that the contemporary derived sources were responsible for five times higher carbon emission than the fossil sources (Figure 4) in Debrecen in 2011. The monthly mass concentration of the contemporary carbon varied from 1.5 to $12.9 \mu \mathrm{g} / \mathrm{m}^{3}$ in Debrecen during the investigated year. The maxima of the mass concentration of fossil fraction, contrary to the contemporary value, was observed in February 2011. The trend obtained for the mass concentration of total carbon and total $\mathrm{PM}_{2.5}$ mode can be observed in this case as well.

\section{Comparison with the Local Atmospheric Fossil $\mathrm{CO}_{2}$ Excess Data}

The sampling of atmospheric $\mathrm{PM}_{2.5}$ for AMS ${ }^{14} \mathrm{C}$ measurement was initiated along with ongoing analyses of monthly atmospheric $\mathrm{CO}_{2}$ mole fraction and specific ${ }^{14} \mathrm{C}$ content determined by GPC observations of atmospheric $\mathrm{CO}_{2}$. In this way, the fossil $\mathrm{CO}_{2}$ excess data and fossil carbonaceous aerosol fraction data were obtained and could be directly compared. In Figure 5, the fossil carbon fraction of the $\mathrm{PM}_{2.5}$ mode originating from the Debrecen sampling site is given in units of $\mu \mathrm{g} / \mathrm{m}^{3}$, with the atmospheric fossil $\mathrm{CO}_{2}$ excess in $\mu \mathrm{mol} / \mathrm{mol}$.

The atmospheric fossil $\mathrm{CO}_{2}$ excess data presented and compared to the fossil carbon mass concentration in $\mathrm{PM}_{2.5}$ mode are calculated based on Equation 3. Measuring both the mole fraction of atmospheric $\mathrm{CO}_{2}$ gas and its specific ${ }^{14} \mathrm{C}$ content, the fossil-derived difference between a background site and an investigated site (Debrecen in this study) can be calculated.

During the period between November 2010 and January 2011, some alterations in the fossil carbon fraction of $\mathrm{PM}_{2.5}$ were observed, and a sudden significant increase was found in February 2011 


\section{Corrected Proofs}

Fossil Carbon in Atmospheric $\mathrm{PM}_{2.5}$ and $\mathrm{CO}_{2}$ in Debrecen, Hungary

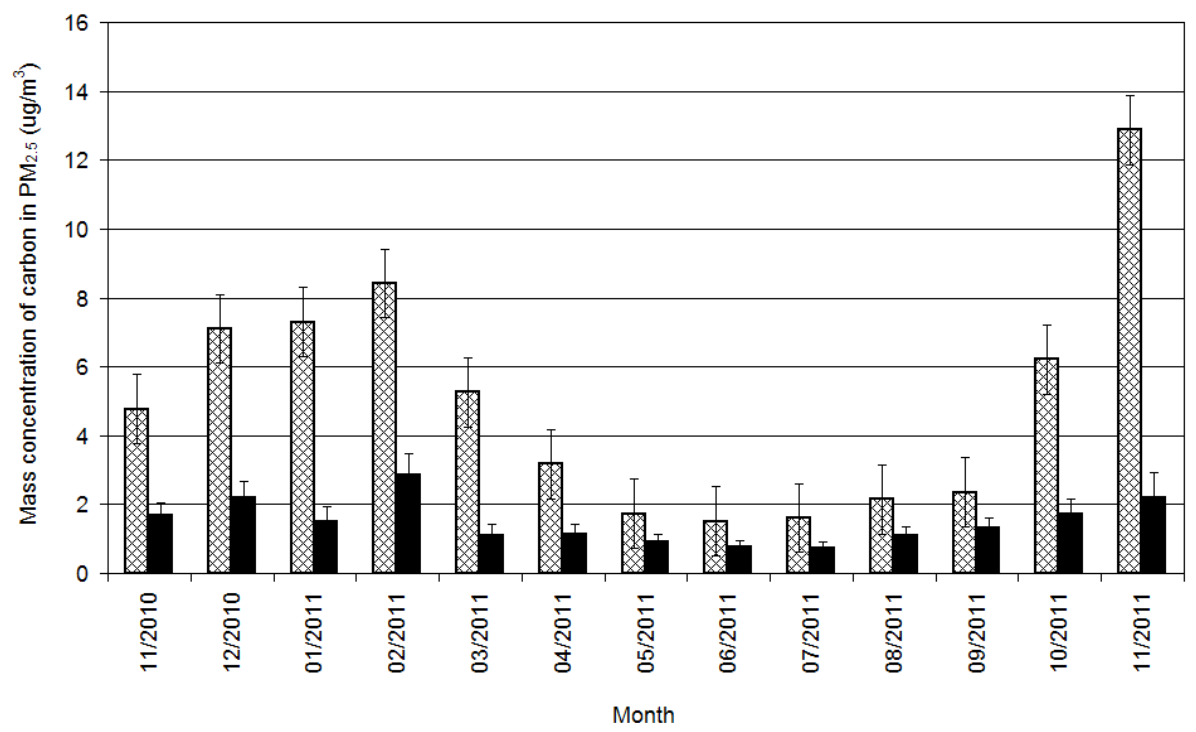

Figure 4 Annual variation of monthly average mass concentration of the contemporary and fossilderived carbon calculated by means of the individual $\mathrm{f}_{\mathrm{C}}$ values and monthly total carbon data. Checked bars represent the contemporary carbon mass concentration, while black bars represent the fossil carbon mass concentration in the fine aerosol mode $\left(\mathrm{PM}_{2.5}\right)$.

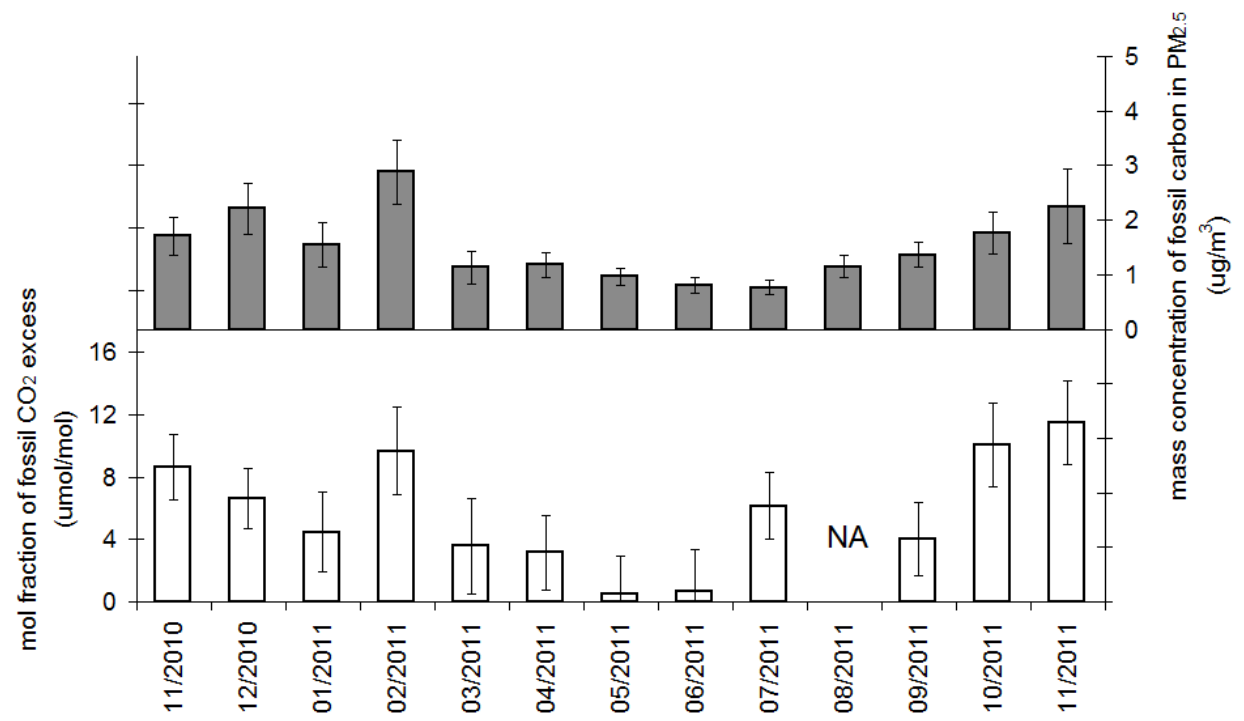

Figure 5 Trends of the mass concentration of fossil carbon in $\mathrm{PM}_{2.5}$ mode and mole fraction of fossil $\mathrm{CO}_{2}$ excess in 2010-2011.

followed by a rapid decrease. Variations of fossil contribution to atmospheric $\mathrm{CO}_{2}$ and $\mathrm{PM}_{2.5}$ show larger differences from May to July 2011. $\mathrm{PM}_{2.5}$ showed a stable but relatively smaller fossil carbon concentration (around $1 \mu \mathrm{g}$ carbon $/ \mathrm{m}^{3}$ ) in the summer.

The identical change of the atmospheric absolute concentration of the fossil components (aerosol and $\mathrm{CO}_{2}$ ), observed in the more recent data as well, unambiguously shows that the presence of the fossil aerosol and the fossil $\mathrm{CO}_{2}$ excess in the atmosphere are both related to the use of fossil fuels 


\section{Corrected Proofs}

and are regulared by the meteorological conditions. Actual atmospheric concentrations of carbonaceous aerosol and $\mathrm{CO}_{2}$ are clearly influenced by many different independent sources and effects (i.e. biological and anthropological load, meteorological conditions, sinks) and have very different production mechanisms. On the other hand, the fossil components are mostly produced by combustion of fossil fuels. If the use of fossil fuel is increases or decreases, then the amount of emitted fossil $\mathrm{CO}_{2}$ and fossil aerosol will rise or fall in the same rhythm. This could be the reason why in some cases the observed trend of the mass concentration of fossil carbon in the aerosol varies in a similar way to the trend of atmospheric fossil $\mathrm{CO}_{2}$ excess. So far, we have not found any published continuous data set regarding the coincidences of fossil carbonaceous aerosol and fossil $\mathrm{CO}_{2}$ data measured on monthly integrated samples.

\section{SUMMARY}

This article presents the first results of a new, simplified aerosol preparation process applied at the HEKAL laboratory for ${ }^{14} \mathrm{C}$ investigation of carbon content of bulk $\mathrm{PM}_{2.5}$ mode. As a case study, the contemporary and fossil carbon fractions of monthly atmospheric fine aerosol of Debrecen for a 1-yr-long period were determined. We studied the organic and elemental (black) carbonaceous constituents together (TC). Using AMS ${ }^{14} \mathrm{C}$ analyses, the contemporary carbon fraction $\left(\mathrm{f}_{\mathrm{C}}\right)$ of the samples was determined and quantitative distinction was made between the recent and fossil aerosol contributions for each month of the observation year.

The carbon fraction of the aerosol samples varied between the summer $(21 \%)$ and winter (31\%) in the city center of Debrecen during 2011. The mean value of $\mathrm{f}_{\mathrm{C}}$ was 0.73 , ranging from the summer (May-September) minimum of about 0.64 to the winter maximum of 0.85 . As there is only minimal natural plant biological activity in Debrecen in wintertime, it can be concluded that the constantly high recent carbon fraction comes from anthropogenic sources such as combustion of firewood and biomass. Although biodiesel contains modern carbon as well, its use is not widespread in the region and does not show seasonality; therefore, its effect cannot be significant.

The fossil fraction of atmospheric $\mathrm{CO}_{2}$ excess and that of $\mathrm{PM}_{2.5}$ aerosol varied similarly for a few months, indicating that they have the same type of origin, namely fossil fuel combustion. This observation confirms that the fossil fraction contribution of the two atmospheric carbonaceous constituents (aerosol and $\mathrm{CO}_{2}$ ) might be investigated together, which could lead to a better understanding and identification of different pollution sources.

\section{ACKNOWLEDGMENTS}

This research was supported by the European Union and the State of Hungary, co-financed by the European Social Fund in the framework of TÁMOP 4.2.4.A/2-11-1-2012-0001 'National Excellence Program and TÁMOP-4.2.2.A-11/1/KONV-2012-0043 'ENVIKUT' Program. This project was supported by the Hungarian NSF (Ref no. OTKA-MB08A-81515 and OTKA-CK77550), the János Bolyai Research Scholarship of the Hungarian Academy of Sciences and Isotoptech Ltd. This work was performed in part of the New Hungary Development Plan under Project No. GOP-2.1.109/A-2009-2008 and GOP-1.3.1-09/A-2009-0032.

\section{REFERENCES}

AQEG (Air Quality Expert Group). 2005. Particulate matter in the United Kingdom. Second report of the AQEG, UK Department for Environment, Food and Rural Affairs. PB10580, London.

Bench G, Fallon S, Schichtel B, Malm W, McDade C.
2007. Relative contributions of fossil and contemporary carbon sources to $\mathrm{PM}_{2.5}$ aerosols at nine Interagency Monitoring for Protection of Visual Environments (IMPROVE) network sites. Journal of Geophysical Research 112:D10205. 


\section{Corrected Proofs}

Fossil Carbon in Atmospheric $\mathrm{PM}_{2.5}$ and $\mathrm{CO}_{2}$ in Debrecen, Hungary

Borbély-Kiss I, Kertész Zs, Koltay E, Szabó Gy, Tar K. 1999. Composition of urban and rural aerosol samples collected in the Great Hungarian Plain. Nuclear Instruments and Methods in Physics Research B 150(1-4):339-44.

Burr GS, Jull AJT. 2009. Accelerator mass spectrometry for radiocarbon research. In: Gross ML, Caprioli R, editors. Encyclopedia of Mass Spectrometry. Volume 5. Amsterdam: Elsevier. p 656-69.

Cachier H. 1998. Carbonaceous combustion aerosols. In: Harrison RM, van Grieken R, editors. Atmospheric Particles. IUPAC series on analytical and physical chemistry of environmental systems, Volume 5. Chichester: John Wiley \& Sons. p 295-348.

Chow JC, Watson JG. 2002. PM ${ }_{25}$ carbonate concentrations at regionally representative Interagency Monitoring of Protected Visual Environment sites. Journal of Geophysical Research 107:8344.

Chow JC, Watson JG, Chen LWA, Arnott WP, Moosmuller H. 2004. Equivalence of elemental carbon by thermal/optical reflectance and transmittance with different temperature protocols. Environmental Science \& Technology 38(16):4414-22.

Clayton GD, Arnold JR, Patty FA. 1955. Determination of sources of particulate atmospheric carbon. Science 122(3173):751-3.

Csongor É, Hertelendi E. 1986. Low-level counting facility for ${ }^{14} \mathrm{C}$ dating. Nuclear Instruments and Methods in Physics Research B 17(5-6):493-5.

Csongor É, Szabó I, Hertelendi E. 1982. Preparation of counting gas of proportional counters for radiocarbon dating. Radiochemical and Radioanalytical Letters 55(5-6):303-7.

Currie LA. 2000. Evolution and multidisciplinary frontiers of ${ }^{14} \mathrm{C}$ aerosol science. Radiocarbon $42(1): 115$ 26.

Currie LA, Stafford TW, Sheffield AE, Klouda GA, Wise SA, Fletcher RA, Donahue DJ, Jull AJT, Linick TW. 1989. Microchemical and molecular dating. Radiocarbon 31(3):448-63.

Endo M, Yamamoto N, Yoshinaga J, Yanagisawa Y, Endo O, Goto S, Yoneda M, Shibata Y, Morita M. 2004. ${ }^{14} \mathrm{C}$ measurement for size fractionated airborne particulate matters. Atmospheric Environment 38(36):6263-7.

Environmental Program of Debrecen. 2009-2014. Plánum 97 Kft. 2009. Debrecen. In Hungarian.

Heal MR, Naysmith P, Cook GT, Xu S, Duran TR, Harrison RM. 2011. Application of ${ }^{14} \mathrm{C}$ analyses to source apportionment of carbonaceous $\mathrm{PM}_{25}$ in the UK. At mospheric Environment 45(36): 2341-8.

Heintzenberg J. 1989. Fine particles in the global troposphere: a review. Tellus B 41:149-60.

Hertelendi E. 1990. Developments of methods and equipment for isotope analytical purposes and their applications [CSc thesis]. Hungarian Academy of Sciences. In Hungarian.

Huang J, Kang S, Shen C, Cong Z, Liu K, Wang W, Liu L. 2010. Seasonal variations and sources of ambient fossil and biogenic-derived carbonaceous aerosols based on ${ }^{14} \mathrm{C}$ measurements in Lhasa, Tibet. Atmospheric Research 96(4):553-9.

Krivácsy Z, Sávári Z, Temesi D, Baltensperger U, Nyeki S, Weingartner E, Kleefeld S, Jennings SG. 2001. Role of organic and black carbon in the chemical composition of atmospheric aerosol at European background sites. Atmospheric Environment 35(36):6231-44.

Künzli N, Kaiser R, Medina S, Studnicka M, Chanel O, Filliger P, Herry M, Horak F Jr, Puybonnieux-Texier V, Quénel P, Schneider J, Seethaler R, Vergnaud JC, Sommer H. 2000. Public-health impact of outdoor and traffic-related air pollution: a European assessment. The Lancet 356(9232):795-801.

Larssen S, Sluyter R, Helmis C. 1999. Criteria for EUROAIRNET, the EEA air quality monitoring and information network. Technical Report NO12.

Levin I, Kromer B, Schmidt M, Sartorius H. 2003. A novel approach for independent budgeting of fossil fuel $\mathrm{CO}_{2}$ over Europe by ${ }^{14} \mathrm{CO}_{2}$ observations. Geophysical Research Letters 30(23):2194.

Molnár A, Mészáros E, Hansson HC, Karlsson H, Gelencsér A, Kiss Gy, Kriváncsy Z. 1999. The importance of organic and elemental carbon in the fine atmospheric aerosol particles. Atmospheric Environment 33:2745-50.

Molnár M, Bujtás T, Svingor É, Futó I, Svetlik I. 2007. Monitoring of atmospheric excess ${ }^{14} \mathrm{C}$ around Paks Nuclear Power Plant, Hungary. Radiocarbon 49(2):1031-43.

Molnár M, Haszpra L, Svingor É, Major I, Svetlik I. 2010a. Atmospheric fossil fuel $\mathrm{CO}_{2}$ measurement using a field unit in a central European city during the winter of 2008/09. Radiocarbon 52(2):835-45.

Molnár M, Major I, Haszpra L, Svetlik I, Svingor É, Veres M. 2010b. Fossil fuel $\mathrm{CO}_{2}$ estimation by atmospheric ${ }^{14} \mathrm{C}$ measurement and $\mathrm{CO}_{2}$ mixing ratios in the city of Debrecen, Hungary. Journal of Radioanalytical and Nuclear Chemistry 286(2):471-6.

Molnár M, Janovics R, Major I, Orsovszki J, Gönczi R, Veres M, Leonard AG, Castle SM, Lange TE, Wacker L, Hajdas I, Jull AJT. 2013a. Status report of the new AMS ${ }^{14} \mathrm{C}$ sample preparation lab of the Hertelendi Laboratory of the Environmental Studies (Debrecen, Hungary). Radiocarbon 55(2-3):665-76.

Molnár M, Rinyu L, Veres M, Seiler M, Wacker L, Synal HA. 2013b. EnvironMICADAS: a mini ${ }^{14} \mathrm{C}$ AMS with enhanced gas ion source interface in the Hertelendi Laboratory of Environmental Studies (HEKAL), Hungary. Radiocarbon 55(2-3):338-44.

Novakov T, Hegg DA, Hobbs PV. 1997. Airborne measurements of carbonaceous aerosols on the East Coast of the United States. Journal of Geophysical Research Atmospheres 102(D25):30,023-30.

Pedersen M, Giorgis-Allemand L, Bernard C, Aguilera I, Andersen AMN, Ballester F, Beelen RMJ, Chatzi L, Cirach M, Danileviciute A, Dedele A, van Eijsden M, Estarlich M, Fernández-Somoano A, Fernández MF, Forastiere F, Gehring U, Grazuleviciene R, Gruzieva O, Heude B, Hoek G. 2013. Ambient air 


\section{Corrected Proofs}

pollution and low birth weight: a European cohort study (ESCAPE). The Lancet Respiratory Medicine 1(9):695-704.

Pöschl U. 2005. Atmospheric aerosols: composition, transformation, climate and health effects. Angewandte Chemie 44:7520-40.

Putaud JP, Van Dingenen R, Alastuey A, Bauer H, Birmili Cyrys J, Flentje H, Fuzzi S, Gehrig R, Hansson HC, Harrison RM, Herrmann H, Hitzenberger R, Hüglin C, Jones AM, Kasper-Giebl A, Kiss G, Kousa A, Kuhlbusch TAJ, Löschau G, Maenhaut W, Molnar A, Moreno T, Pekkanen J, Perrino C, Pitz M, Puxbaum H, Querol X, Rodriguez S, Salma I, Schwarz J, Smolik J, Schneider J, Spindler G, ten Brink H, Tursic J, Viana M, Wiedensohler A, Raes F. 2010. A European aerosol phenomenology - 3: Physical and chemical characteristics of particulate matter from 60 rural, urban, and kerbside sites across Europe. Atmospheric Environment 44(10):1308-20.

Ramanathan V, Ramana MV, Roberts G, Kim D, Corrigan C, Chung C, Winker D. 2007. Warming trends in Asia amplified by brown cloud solar absorption. Nature 448(7153):575-8.

Rinyu L, Molnár M, Major I, Nagy T, Veres M, Kimák Á, Wacker L, Synal H-A. 2013. Optimization of sealed tube graphitization method for environmental ${ }^{14} \mathrm{C}$ studies using MICADAS. Nuclear Instruments and Methods in Physics Research B 294(1):270-5.

Rogge WF, Hildemann LM, Mazurek MA, Cass GR, Simoneit BRT. 1993. Sources of fine organic aerosol. 4. Particulate abrasion products from leaf surfaces of urban plants. Environmental Science and Technology 27(4):2700-11.

Saxena P, Hildemann LM, McMurry PH, Seinfeld JH. 1995. Organics alter hygroscopic behavior of atmospheric particles. Journal of Geophysical Research 100(D9): $18,755-70$.
Stuiver M, Polach H. 1977. Discussion: reporting of ${ }^{14} \mathrm{C}$ data. Radiocarbon 19(3):355-63.

Szidat S, Jenk TM, Gaggeler HW, Synal H-A, Fisseha R, Baltensperger U, Kalberer M, Samburova V, Reimann S, Kasper-Giebl A, Hajdas I. 2004. Radiocarbon $\left({ }^{14} \mathrm{C}\right)$-deduced biogenic and anthropogenic contributions to organic carbon (OC) of urban aerosols from Zurich, Switzerland. Atmospheric Environment 38(24):4035-44.

Szidat S, Jenk TM, Synal H-A, Kalberer M, Wacker L, Hajdas I, Kasper-Giebl A, Baltensperger U. 2006. Contributions of fossil fuel, biomass-burning, and biogenic emissions to carbonaceous aerosols in Zurich as traced by ${ }^{14} \mathrm{C}$. Journal of Geophysical Research 111:D07206..

Szidat, S, Ruff M, Perron N, Wacker L, Synal HA, Hallquist M, Shannigrahi AS, Yttri KE, Dye C, Simpson D. 2009. Fossil and non-fossil sources of organic carbon (OC) and elemental carbon (EC) in Goteborg, Sweden. Atmospheric Chemistry and Physics 9:1521-35.

Tanner RL, Parkhurst WJ, Valente ML, Phillips WD. 2004. Regional composition of $\mathrm{PM}_{2.5}$ aerosols measured at urban, rural and "background" sites in the Tennessee valley. Atmospheric Environment 38(20):3143-53.

Turpin BJ, Saxena P, Andrews E. 2000. Measuring and simulating particulate organics in the atmosphere: problems and prospects. Atmospheric Environment 34(18):2983-3013

Uchrin G, Hertelendi E. 1992. Development of a reliable differential Carbon-14 sampler for environmental air and NPP stack monitoring. Final Report of the OMFB contract No. 001

Wacker L, Christl M, Synal H-A. 2010. Bats: a new tool for AMS data reduction. Nuclear Instruments and Methods in Physics Research B 268(7-8):976-9. 